\title{
Hubungan penggunaan smartphone dengan fungsi penglihatan pada mahasiswa Fakultas Kedokteran Universitas Sam Ratulangi Manado angkatan 2016
}

\author{
${ }^{1}$ Christo F. N. Bawelle \\ ${ }^{2}$ Fransiska Lintong \\ 2Jimmy Rumampuk \\ ${ }^{1}$ Kandidat Skripsi Fakultas Kedokteran Universitas Sam Ratulangi \\ ${ }^{2}$ Bagian Fisika Fakultas Kedokteran Universitas Sam Ratulangi \\ Email: natanelchristo@yahoo.com
}

\begin{abstract}
Smartphone is a kind of cellular phone that has high capability, and worked by radiate the electromagnetic radiation of radio frequency. The eye is visual sense that can capture the reflected light beam of an object. The increased of using smartphone nowadays made the community worry about the effects of smartphone radiation for health especially on the visual function. Objective: To know the correlation between the duration of using smartphone with visual function, and to know the correlation between the intensity of using smartphone with visual function in students of Medical Faculty Unsrat 2016 generation. Method: The research conducted was analytic survey with used cross sectional approach, the research conducted on Oktober 2016 at Department of Physics in Medical Faculty of Manado Sam Ratulangi University. Result: Based on the analysis result by Chi Square test obtained $p=0,033$ which means there was the correlation between the duration of using smartphone with the visual function, and there was no correlation the between intensity of using smartphone with visual function with score $\mathrm{p}=0,786$. Conclusion: There was a correlation between the duration of using smartphone with visual function in students of Medical Faculty Manado Sam Ratulangi University. There was no correlation between the intensity of using smartphone with visual function in students of Medical Faculty Manado Sam Ratulangi University.
\end{abstract}

Keywords: smartphone, visual function

\begin{abstract}
Abstrak: Smartphone merupakan sejenis telepon seluler yang mempunyai kemampuan tinggi, dan bekerja dengan cara memancarkan sejenis radiasi elektromagnetik radio frekuensi. Mata merupakan indra penglihatan yang dapat menangkap berkas cahaya yang dipantulkan dari sebuah benda. Peningkatan penggunaan smartphone di era sekarang ini menimbulkan kekhawatiran pada masyarakat tentang efek radiasi sinar smartphone terhadap kesehatan terutama fungsi penglihatan. Tujuan: Untuk mengetahui hubungan antara lama penggunaan smartphone dengan fungsi penglihatan, dan untuk mengetahui hubungan antara intensitas penggunaan smartphone dengan fungsi penglihatan pada mahasiswa Fakultas Kedokteran Unsrat angkatan 2016. Metode: Penelitian yang dilakukan bersifat survei analitik dengan menggunakan pendekatan cross sectional, penelitian dilakukan pada bulan Oktober 2016 di Bagian Fisika Fakultas Kedokteran Universitas Sam Ratulangi Manado. Hasil: Berdasarkan hasil analisis dengan uji Chi Square diperoleh $p=0,033$ yang artinya ada hubungan lama penggunaan smartphone dengan fungsi penglihatan. Tidak terdapat hubungan secara statistik antara intensitas pengguanaan smartphone dengan fungsi penglihatan dengan nilai $p=0,786$. Simpulan: Ada hubungan antara lama penggunaan smartphone dengan fungsi penglihatan pada Mahasiswa Fakultas Kedokteran Universitas Sam Ratulangi. Tidak ada hubungan antara intensitas penggunaan smartphone dengan fungsi penglihatan pada Mahasiswa Fakultas Kedokteran Universitas Sam Ratulangi.
\end{abstract}

Kata kunci: smartphone, fungsi penglihatan 
Penggunaan telepon seluler sekarang ini menjadi bagian dari kebutuhan dan gaya hidup sehari-hari. ${ }^{1}$ Smartphone merupakan sejenis telepon seluler yang mempunyai kemampuan lebih tinggi dari yang biasa dengan kemampuan seperti komputer, biasanya memiliki layar yang besar dan sistem operasinya mampu menjalankan tujuan aplikasi-aplikasi yang umum. ${ }^{2}$

Tahun 2009 penggunaan telepon seluler meningkat dalam jumlah besar diseluruh dunia yaitu lebih dari 4,3 miliar pengguna. $^{3}$ Dari data Kementrian Komunikasi dan Informasi di tahun 2015, Indonesia diperkirakan memiliki sekitar 55 juta pengguna smartphone, dan termasuk 5 besar pengguna smartphone di dunia dan diperkirakan akan meningkat pada tahun 2017..$^{4,5}$

Telepon seluler bekerja dengan cara memancarkan sejenis radiasi elektromagnetik radio frekuensi. Pengeluaran energi maksimal radiasi elektromagnetik dari telepon seluler berkisar 0,6-1 watt. ${ }^{1}$ Pengukur energi radio frekuensi (RF) yang diserap oleh jaringan tubuh pengguna telepon seluler bisa dinyatakan sebagai unit dari watt perkilogram (W/kg). Pengukuran ini bertujuan untuk menentukan apakah telepon seluler sesuai dengan panduan-panduan keselamatan. ${ }^{6}$

Optik merupakan alat bantu penglihatan yang penting dalam kehidupan, salah satunya adalah mata. Mata merupakan indra penglihatan yang dapat menangkap berkas cahaya yang dipantulkan dari sebuah benda. Jika lensa yang dilalui cahaya menjadi sangat kecil sehingga ukurannya mendekati panjang gelombang dari cahaya tersebut, maka muncullah fenomena difraksi. ${ }^{7}$

Cedera dan penyakit mata bisa mempengaruhi penglihatan. Kejernihan penglihatan disebut visus. Jika ketajaman menurun, penglihatan menjadi kabur. Ketajaman penglihatan biasanya diukur dengan skala yang membandingkan penglihatan seseorang pada jarak 6 meter. Visus 6/6 artinya seseorang melihat benda jarak 6 meter dengan tajam penuh. ${ }^{8}$
Para ahli mengatakan bahwa smartphone semakin sering diproduksi dengan layar lebih cerah digunakan siang dan malam, dan kemungkinan akan lebih sering terjadi. Menggunakan smartphone di tempat tidur dan dalam gelap dapat menyebabkan penurunan fungsi penglihatan. Peningkatan penggunaan smartphone di era sekarang ini menimbulkan kekhawatiran pada masyarakat tentang efek negatif radiasi sinar smartphone terhadap kesehatan salah satunya fungsi penglihatan., ${ }^{1,9}$

Berdasarkan pemaparan diatas, maka penulis terdorong untuk melakukan penelitian agar dapat mengetahui hubungan penggunaan smartphone dengan fungsi penglihatan pada mahasiswa Fakultas Kedokteran angkatan 2016.

\section{METODE PENELITIAN}

Penelitian ini dilakukan secara survei analitik dengan menggunakan pendekatan cross sectional. Populasi adalah seluruh mahasiswa Fakultas Kedokteran Universitas Sam Ratulangi angkatan 2016 yang memiliki smartphone, sampel adalah mahasiswa yang memenuhi kriteria inklusi.

Popilasi diberikan kuesioner untuk untuk menentukan sampel yang akan diteliti yang kemudian stelah mengisi informed consent, dilakukan pemeriksaan tajam penglihatan menggunaka Snellen Chart. Data kemudian dianalisis menggunakan Statical Program for Social Science (SPSS) For Windows kemudian disajikan dalam bentuk tabel dan diagram.

\section{HASIL PENELITIAN}

Berdasarkan penelitian yang dilakukan didapatkan sampel sebanyak 50 orang dengan karakteristik responen sebagai berikut:

Responden berjenis kelamin perempuan memiliki jumlah lebih banyak yaitu 36 orang dengan persentase (72\%) dibandingkan dengan jenis kelamin laki-laki yang berjumlah 14 orang dengan persentase $(28 \%)$. 
Tabel 1. Karakteristik Responden Menurut Jenis Kelamin

\begin{tabular}{ccc}
\hline Jenis Kelamin & $\mathrm{n}$ & $\%$ \\
\hline Laki-laki & 14 & 28 \\
Perempuan & 36 & 72 \\
\hline \multicolumn{1}{c}{ Total } & 50 & 100 \\
\hline
\end{tabular}

Tabel 2. Karakteristik Responden Berdasarkan Lama Penggunaan Smartphone

\begin{tabular}{ccc}
\hline $\begin{array}{c}\text { Lama Penggunaan } \\
\text { Smartphone }\end{array}$ & $\mathrm{n}$ & $\%$ \\
\hline 1-2 Tahun & 2 & 4 \\
2-3 Tahun & 3 & 6 \\
>3 Tahun & 45 & 90 \\
\hline Total & 50 & 100 \\
\hline
\end{tabular}

Responden yang menggunakan samrtphone selama $>3$ tahun sebanyak 45 responden dengan persentase $(90 \%)$, dan paling sedikit yaitu 2 responden $(4 \%)$ telah menggunakan samrtphone selama 1-2 tahun.

Tabel 3. Karakteristik Responden Berdasarkan Intensitas Penggunaan

\begin{tabular}{ccc}
\hline Intensitas & & \\
Penggunaan & $\mathrm{n}$ & $\%$ \\
\hline 2-3 Jam & 1 & 2 \\
3-4 Jam & 5 & 10 \\
>4 Jam & 44 & 88 \\
\hline Total & 50 & 100 \\
\hline
\end{tabular}

Sebagian besar data yaitu 44 responden $(88 \%)$ menggunakan smartphone selama $>4$ jam per hari, dan penggunaan 2-3 jam per hari hanya 1 responden $(2 \%)$.
Tabel 4. Karakteristik Responden Berdasarkan Riwayat Penyakit Mata

\begin{tabular}{ccc}
\hline Riwayat Penyakit Mata & $\mathrm{n}$ & $\%$ \\
\hline Ada & 5 & 10 \\
Tidak & 45 & 90 \\
\hline Total & & \\
\hline
\end{tabular}

Tabel 4 menunjukan bahwa 5 responden $(10 \%)$ memiliki riwayat penyakit mata, sedangkan 45 responden $(90 \%)$ tidak memiliki riwayat penyakit mata.

Tabel 5. Karakteristik Responden Berdasarkan Hasil Pemeriksaan Mata Kanan

\begin{tabular}{ccc}
\hline Visus & $\mathrm{n}$ & $\%$ \\
\hline $6 / 6$ & 42 & 84 \\
$6 / 7.5$ & 8 & 16 \\
\hline Total & 50 & 100 \\
\hline
\end{tabular}

Responden dengan visus 6/6 sebanyak 42 responden (84\%), dan visus 6/7.5 sebanyak 8 responden (16\%).

Tabel 6. Karakteristik Responden Berdasarkan Hasil Pemeriksaan Mata Kiri

\begin{tabular}{ccc}
\hline Visus & $\mathrm{n}$ & $\%$ \\
\hline $6 / 6$ & 40 & 80 \\
$6 / 7.5$ & 7 & 14 \\
$6 / 9$ & 2 & 4 \\
$6 / 12$ & 1 & 2 \\
\hline Total & 50 & 100 \\
\hline
\end{tabular}

Pada responden terdapat visus 6/6 sebanyak 40 responden $(80 \%), 7$ responden (14\%) dengan visus 6/7.5, 2 responden (4\%) dengan visus $6 / 9$, dan 1 responden $(2 \%)$ dengan visus $6 / 12$. 
Bawelle, Lintong, Rumampuk: Hubungan penggunaan smartphone...

Tabel 7. Hasil tabulasi silang lama penggunaan smartphone dengan fungsi penglihatan

\begin{tabular}{|c|c|c|c|c|c|c|c|c|c|}
\hline & & \multicolumn{6}{|c|}{ Kriteria Penurunan } & \multirow{2}{*}{$P$} & \multirow{2}{*}{ Kesimpulan } \\
\hline & & Normal & $\%$ & Penurunan & $\%$ & Jumlah & $\%$ & & \\
\hline \multirow{3}{*}{$\begin{array}{c}\text { Lama } \\
\text { pengguna } \\
\text { an } \\
\text { smartpho } \\
\text { ne }\end{array}$} & $\begin{array}{l}1-2 \\
\text { thn }\end{array}$ & 0 & 0.0 & 2 & 4.0 & 2 & $\begin{array}{c}4 . \\
0\end{array}$ & \multirow{3}{*}{$\begin{array}{c}0.03 \\
3\end{array}$} & \multirow{3}{*}{ Ada Hubungan } \\
\hline & $\begin{array}{l}2-3 \\
\text { thn }\end{array}$ & 3 & 6.0 & 0 & 0.0 & 3 & $\begin{array}{l}6 . \\
0\end{array}$ & & \\
\hline & $\begin{array}{l}>3 \\
\text { thn }\end{array}$ & 34 & $\begin{array}{c}68 . \\
0\end{array}$ & 11 & 22.0 & 45 & $\begin{array}{l}99 \\
0 . \\
0\end{array}$ & & \\
\hline Total & & 37 & $\begin{array}{l}74 . \\
0\end{array}$ & 13 & 26.0 & 50 & $\begin{array}{l}1 \\
0 \\
0\end{array}$ & & \\
\hline
\end{tabular}

Tabel 8. Hasil tabulasi silang intensitas penggunaan smartphone dengan fungsi penglihatan

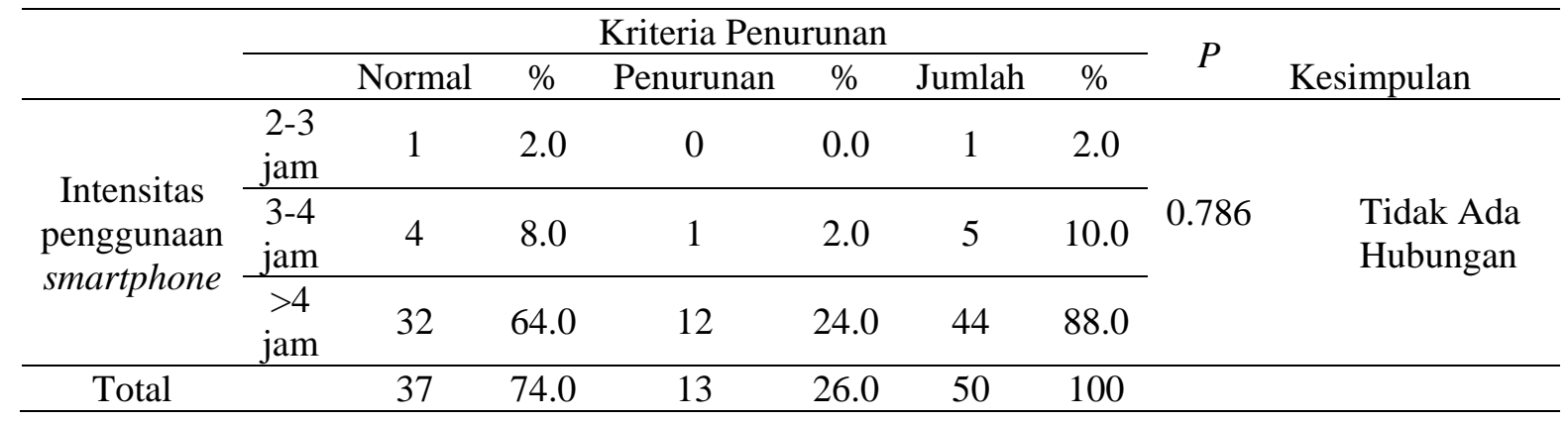

\section{BAHASAN}

Pada penelitian ini responden yang diteliti berjumlah 50 orang, yang terdiri dari 14 responden laki-laki dengan persentase (28\%) dan 36 responden perempuan dengan persentase $(72 \%)$ dengan rentang umur 1620 tahun, dimana semua telah memenuhi kriteria inklusi termasuk tidak menggunakan alat bantu melihat. Hasil pemeriksaan mata kanan menunjukan bahwa 8 orang $(16 \%)$ responden memiliki visus di bawah normal, sedangkan 42 responden (84\%) memiliki tajam penglihatan oculo dextra dengan nilai visus normal. Sedangkan hasil pemeriksaan pada mata kiri menunjukan bahwa 10 responden (20\%) memiliki visus di bawah nilai normal dan 40 responden $(80 \%)$ sisanya memiliki visus oculo sinistra normal. Haeny (2009) menyebutkan semakin muda seseorang maka kebutuhan cahaya akan lebih sedikit dibandingkan dengan usia yang lebih tua dan kecenderungan mengalami kelelahan mata

lebih sedikit. Hal serupa dikemukakan Gabriel (2013) dimana kemampuan lensa mata dalam memfokuskan objek tergantung pada umur. Selain itu Ilias (2014) juga menyebutkan semakin tua usia maka kemampuan akomodasi semakin menurun. ${ }^{12,10,11}$

Berdasarkan analisis pada tabel 11 dapat dilihat bahwa semua responden dengan penggunaan smartphone 2-3 tahun tidak mengalami penurunan tajam penglihatan, untuk pengguna smartphone 12 tahun terdapat 2 responden (4\%) dengan visus di bawah normal, dan untuk pengguna smartphone $>3$ tahun terdapat 11 responden (22\%) dengan nilai visus di bawah normal. Analisis data bivariat yang digunakan untuk mengetahui hubungan lama penggunaan smartphone dengan fungsi penglihatan adalah Chi-Square, $\alpha=0,05$ diperoleh $p=$ $0,033(\mathrm{p}<0,05)$, sehingga hipotesis $1\left(\mathrm{H}_{1}\right)$ 
diterima dan hipotesis $0 \quad\left(\mathrm{H}_{0}\right)$ ditolak menunjukkan bahwa ada hubungan lama penggunaan smartphone dengan fungsi penglihatan dalam hal ini tajam penglihatan(visus). Hasil ini tidak sejalan dengan penelitian sebelumnya yang serupa yang dilakukan. Ningsih (2013) mengatakan bahwa tidak terdapat hubungan antara lama penggunaan laptop dengan gangguan penglihatan. ${ }^{14}$

Berdasarkan analisis pada tabel 12 dapat dilihat bahwa dari 50 responden 37 (74\%) diantaranya memiliki visus normal, dan $13(26 \%)$ sisanya didapati penurunan visus. Pada tabel juga dapat dilihat 12 (24\%) responden dengan intensitas penggunaan smartphone $>4$ jam memiliki visus di bawah nilai normal atau terjadi penurunan, sedangakan untuk intensitas penggunaan 34 jam terdapat 1 responden dengan penurunan visus. Analisis data yang digunakan untuk mengetahui hubungan intensitas penggunaan samrtphone dengan fungsi penglihatan adalah uji Chi-Square. Hasil analisis data diperoleh nilai $p=$ 0.786>0.05 sehingga hipotesis $0 \quad\left(\mathrm{H}_{0}\right)$ diterima dan hipotesis $1\left(\mathrm{H}_{1}\right)$ ditolak, dengan demikian dapat disimpulkan bahwa tidak terdapat hubungan antara intensitas penggunaan smartphone dengan fungsi penglihatan.

Hasil ini dapat dipengaruhi oleh jeda waktu penggunaan yang memungkinkan otot mata untuk berisitirahat sehingga dapat terhindar dari kelelahan. Mata lelah dapat terjadi jika mata fokus kepada objek berjarak dekat dalam waktu yang lama dan otot-otot mata bekerja lebih keras untuk melihat objek terutama jika disertai dengan pencahayaan yang menyilaukan. ${ }^{14}$

Menurut Wedia Ernawati (2015) dalam penelitianya mengatakan tidak terdapat pengaruh secara statistik antar frekuensi lamanya menggunakan gadget terhadap penurunan tajam penglihatan dengan nilai $p$ $=0.112$. Disimpulkan tidak ada pengaruh antar frekuensi lamanya menggunakan gadget terhadap penurunan tajam penglihatan pada anak usia sekolah.Serupa dengan Wedia Ernawati (2015), Ningsih (2013) juga dalam penelitianya tentang
Hubungan Penggunaan Laptop terhadap Fungsi Penglihatan mengatakan tidak terdapat hubungan antara rata-rata waktu penggunaan laptop dengan gangguan pada mata. ${ }^{15,13}$

Berbeda dengan Wedia Ernawati (2015) dan Ningsih (2013) penelitian yang dilakukan oleh Fitri Suciana menunjukan bahwa ada hubungan antara lama penggunaan telepon genggam dengan kelelahan mata di SMA Negeri 3 Klaten. ${ }^{16}$

\section{SIMPULAN}

Terdapat hubungan antara lama penggunaan smartphone dengan fungsi penglihatan pada mahasiswa Fakultas Kedokteran Universitas Sam Ratulangi Manado ( $p=0.033)$ dan tidak terdapat hubungan antara intensitas penggunaan smartphone dengan fungsi penglihatan pada mahasiswa Fakultas Kedokteran Universitas Sam Ratulangi Manado ( $p=0.786)$.

\section{SARAN}

Perlu dilakukan pengukuran tajam penglihatn oleh ahli dalam hal ini dokter spesialis mata dan dengan kelengkapan Trial Lens Set untuk hasil yang lebih mendetail.

Perlu dilakukan penelitian lebih lanjut dengan responden yang lebih banyak.

Perlu dilakukan penelitian lebih lanjut mengenai dampak penggunaan smartphone terhadap dampak kesehatan yang lain.

Perlu dilakukan penyuluhan tentang bagaimana menjaga kesehatan mata.

Pada lembar kuesioner perlu ditambahkan pertanyaan untuk menggali lebih banyak informasi dari reaponden

\section{DAFTAR PUSTAKA}

1. Anies. Electrical Sensitivity Gangguan Kesehatan Akibat Radiasi Elektromagnetik. Jakarta:PT Elex Media Komputindo;2005

2. Definition of smartphone. [diakses 2016 Agustus 21] tersedia dari http://www.oxforddictionaries.com/d efinition/english/smartphone

3. Rani B, Singh U, Maheshwari R. Cell phone radiation and health : an 
outlook. Bulletin of Environment, Pharmacology \& Life Sciences. 2011:8;108.

4. Indonesia raksasa teknologi digital asia. [diakses 2016 Agustus 21] tersedia dari http://www.kominfo.go.id

5. Rumate GP. The Impact Of Social Influence and Product Quality Attributes to Costumer Buying Decision Of Iphone In Manado. Jurnal EMBA. 2014;2;831-840

6. Battung RO. Hubungan radiasi gelombang elektromagnetik telepon seluler terhadap fungsi pendengaran mahasiswa angkatan 2009 Fakultas Kedokteran Universitas Sam Ratulangi Manado.[skripsi]. [Manado].Fakultas Kedokteran Unsrat;2013

7. Mengenal cahaya dan optik. Utami HP. Ganeca Exact. 2007;1-3.

8. Fachrian. 2009. Prevalensi Kelainan Tajam Penglihatan Pada Pelajar Sd " $X$ " Jatinegara Jakarta Timur. Jurnal Kedokteran Universitas Pembangunan Nasional. Jakarta. [diakses 2016 September 6] tersedia dari http://indonesia.digitaljournal.org/ind ex.php/idnmed/article/viewfile/646/6 41.

9. Smartphone Use in Bed 'Causes Temporary Blindness'. WebMD Health News. [diakses 2016 September 6] tersedia dari

http://www.medscape.com/viewarticl e/865458
10.Gabriel JF. Fisika Kedokteran. Jakarta. EGC. 2013:140-200.

11.Ilias HS, Yulianti SR. Ilmu penyakit mata. Edisi kelima. Jakarta. FKUI. 2014:112.

12.Haeny N. Analisis faktor-faktor yang mempengaruhi kelelahan pada mata. [Skripsi]. [Jakarta]. FKM UI;2009

13.Ningsih SS. Hubungan penggunaan laptop terhadap fungsi penglihatan pada mahasiswa angkatan 2011 Fakultas Kedokteran Universitas Sam Ratulangi Manado.[skripsi]. [Manado].Fakultas Kedokteran Unsrat;2013

14.Ilias S. Kelainan Refraksi dan Kacamata. Edisi kedua. Jakarta; Fakultas Kedokteran Universitas Indonesia. 2006

15.Ernawati W. Pengaruh penggunaan gadget terhadap penurunan tajam penglihatan pada anak usia sekolah (6-12 tahun) di SD Muhammadiyah 2 Pontianak Selatan.[Jurnal].[Pontianak] Fakultas Kedokteran Universitas Tanjungpura;2015

16.Suciana F. Hubungan antara lama penggunaan telepon genggam dengan kelelahan mata di SMA Negeri 3 Klaten. Keperawatan Stikes Muhammadiyah Klaten 